\title{
AN ECOLOGICAL PERSPECTIVE ON THE DEPLOYMENT AND DESIGN OF LOW- CRESTED AND OTHER HARD COASTAL DEFENCE STRUCTURES
}

\author{
Airoldi L. $(*)$, Abbiati M. $(*)$, Beck M. W. $\left({ }^{\circ}\right)$, Hawkins S.J. $\left(^{\wedge}\right)$, Jonsson P.R. $\left(^{+}\right)$, \\ Martin D. (\#), Moschella P. S. ( $\left.{ }^{+}\right)$, Sundelöf A. (§), Thompson R. C. (^^), Åberg P. (§) \\ (*) Dipartimento di Biologia Evoluzionistica Sperimentale and Centro Interdipartimentale di Ricerca per \\ le Scienze Ambientali di Ravenna, University of Bologna, Italy \\ $\left(^{\circ}\right)$ The Nature Conservancy, 100 Shaffer Road- LML, University of California, Santa Cruz, CA, 95062, \\ USA \\ $\left(^{\wedge}\right)$ Marine Biological Association of the UK, Plymouth, United Kingdom; Biodiversity and Ecology \\ Division, School of Biological Sciences, University of Southampton, United Kingdom \\ $\left(^{+}\right)$Department of Marine Ecology, Tjärno Marine Biological Laboratory, Göteborg University, Sweden \\ (\#) Centre d'Estudis Avançats de Blanes (Consejo Superior de Investigaciones Científicas), Carrer \\ d'accés a la Cala Sant Francesc 14, 17300 Blanes (Girona), Catalunya (Spain). \\ $(\wedge \wedge)$ School of Biological Sciences, University of Plymouth, United Kingdom \\ (§) Department of Marine Ecology, Göteborg University, Sweden
}

Corresponding author:

Dr Laura Airoldi, Scienze Ambientali, Università di Bologna, Via S. Alberto 163, I-48100, Ravenna, Italy

Phone: +39 0544 937314; Fax: +390544 937303; e-mail: laura.airoldi@unibo.it

Running head: design of LCSs: an ecological perspective

Keywords: artificial habitats, benthic organisms, coastal management, community structure, environmental impact, sea defence, spatial and temporal heterogeneity

\begin{abstract}
Coastal areas play a crucial role in the economical, social and political development of most countries; they support diverse and productive coastal ecosystems that provide valuable goods and services. Globally flooding and coastal erosion represent serious threats along many coastlines, and will become more serious as a consequence of human-induced changes and accelerated sea-level rise. Over the past century, hard coastal defence structures have become ubiquitous features of coastal landscapes as a response to these threats. The proliferation of defence works can affect over half of the natural shoreline in some regions and results in dramatic changes to the coastal environment. Surprisingly little attention has been paid to the ecological consequences of coastal defence. Results from the DELOS
\end{abstract}


(Environmental Design of Low Crested Coastal Defence Structures, EVK3-CT-2000-00041) project indicate that the construction of coastal defence structures will affect coastal ecosystems. The consequences can be seen on a local scale, as disruption of surrounding soft-bottom environments and introduction of new artificial hard-bottom habitats, with consequent changes to the native assemblages of the areas. Proliferation of coastal defence structures can also have critical impacts on regional species diversity, removing isolating barriers, favouring the spread of non-native species and increasing habitat heterogeneity. Knowledge of the environmental context in which coastal defence structures are placed is fundamental to an effective management of these structures as, whilst there are some general consequences of such construction, many effects are site specific. Advice is provided to meet specific management goals, which include mitigating specific impacts on the environment, such as minimising changes to surrounding sediments, spread of exotic species or growth of nuisance species, and/or enhancing specific natural resources, for example enhancing fish recruitment or promoting diverse assemblages for ecoturism. The DELOS project points out that the downstream effects of defence structures on coastal processes and regional-scale impacts on biodiversity necessitate planning and management at a regional (large coastline) scale. To effectively understand and manage coastal defences, environmental management goals must be clearly stated and incorporated into the planning, construction, and monitoring stages.

\section{Introduction}

Erosion of the shoreline and dunes from ocean currents, tidal movements and wave and wind action, is a common natural phenomenon along coastlines all over the world. In Europe coastal erosion has always existed and has shaped coastal landscapes throughout history. An inventory of coastal evolution in the EU undertaken within the EC CORINE programme, showed 55 per cent of the coastline (total length of $56000 \mathrm{~km}$ ) to be stable, 19 per cent to be suffering from erosion problems, and 8 per cent to be depositional (European Environment Agency, 1995). Increased urbanisation and human interventions in coastal processes (including human-induced land subsidence, offshore dredging, decreased sediment supply from rivers, destruction of seagrass meadows, marshes and coastal sand dunes) together with poor coastal defence policies have, however, directly or indirectly turned coastal erosion into a problem of growing intensity (French, 1997; Cencini, 1998). Globally the problem of erosion and flooding will become much more serious because of rising sea levels and an increased storm frequency as a result of global climate change (Bray and Hooke, 1997; National 
Institute of Coastal and Marine Management of the Netherlands, 2004). The recession of coastlines is expected to continue even in the absence of new human activities (Bondesan et al., 1995). At the same time, coastal areas play a crucial role in the economical, social and political development of most countries, and their economic importance is set to grow considerably due to concentration of populations, industries and recreational activities. Estimates indicate that about $70 \%$ of the world's populations live on or within $60 \mathrm{~km}$ from the coast (Hammond, 1992), and the number of people residing in coastal areas will double in the next 30 years (Gray, 1997). Human pressure on the coast is particularly severe in tourist areas (Cencini, 1998), where recreational developments impinge upon the beaches, despite erosion.

As a response to the growing need to defend the coast, hard-substrate defence structures have become common features of coastal landscapes in intertidal and shallow subtidal environments (National Institute of Coastal and Marine Management of the Netherlands, 2004). The primary purposes of defence structures are to prevent or reduce erosion and flooding of high value coastlines, to stabilize and retain beaches and reclaimed land, and to increase the amenity value of the coast (e.g. beach use, surfing). In Europe hard defence structures of different typologies (e.g. breakwaters, groynes, seawalls, dykes or other rock-armoured structures) have proliferated (e.g. see the EU Demonstration Programme 1997-1999 for an updated account of defence works along European coasts, Commission Européenne, 1999), leading to severe artificialization of coastal areas. In some regions, such as the Italian coasts of the Adriatic sea, they cover over half of the natural shoreline resulting in dramatic changes to coastal landscapes and environments (Bacchiocchi and Airoldi, 2003). Surprisingly little attention has, however, been given to the ecological implications of hard coastal defence.

The quality, size and spatial arrangement of habitats are major determinants of the diversity and abundance of species present in an area (Hanski and Gilpin, 1997). These landscape- or regional-scale factors have received wide attention in the management of terrestrial systems for predicting the consequences of urban developments, for the design of nature reserves and to inform restoration plans (Simberloff, 1988). Comparatively less attention has been devoted to the ecology of marine coastal landscapes, particularly those fragmented by the deployment of hard man-made structures such as port installations and coastal defences (Chapman and Bulleri, 2003; 
Connell and Glasby, 1999; Connell, 2001; Davis et al., 2002; ECUS, 2003). In recent years, the growing need in coastal management to balance the many human desires for safety, cost-effectiveness, and the goods and services from coastal ecosystems has stimulated the greater incorporation of ecological knowledge into engineering practices (Bergen et al., 2001). In this context, the European-scale project DELOS (Environmental Design of Low Crested Coastal Defence Structures, EVK3-CT-200000041) was developed. The aim of the project was to promote effective design of lowcrested structures (LCS) to defend European shores while at the same time meeting specific management goals related to the environment, by mitigating impacts on the existing habitats or, when desirable, enhancing specific natural resources in a sustainable manner. The project integrated evaluation of the engineering and socioeconomic performance of LCS with the potential ecological impacts (see Martin et al. and Moschella et al., this issue) at a range of spatial (local, regional and European) and temporal scales (months to years), and in relation to hydrodynamic and environmental conditions.

In the present paper we describe the ecological effects that arise from the deployment of hard defence structures and offer advice on methods for meeting environmental management goals on coastline. These perspectives are based on the results of the DELOS project and other published works. The DELOS project specifically focused on LCSs; from an ecological point of view, however, LCSs function similarly to other types of hard defence structures, such as emerged breakwaters, groynes, dykes, jetties and seawalls (e.g. Bacchiocchi and Airoldi, 2003; Moschella et al this issue), and most of the points raised herein are broadly applicable to any type of hard or rock-armoured artificial structures. We briefly address a number of ecological issues that are crucial to guide engineers and managers responsible for coastal environments. We focus in particular on the importance of natural variation and scale, and a discussion of what is a natural environment and an environmental impact. Then we examine the impacts related to the deployment of hard defence structures drawing upon the case studies of the DELOS project, thereby providing examples of site-specific design options that meet specific management end-points. Finally we summarize the main lessons learned from the DELOS project and their implications for a more sustainable long-term management of coastal areas. 


\section{Biological variation: ecological processes vary in time and space}

The abundance and distribution of species vary in time and space. This variation is a result of the interactions between biological and physical processes (Pickett and White, 1985). The basic processes that set the abundance and distribution of species are recruitment, survival, reproduction and dispersal of individuals of the pool of species in a particular area. Consequently all factors that influence these basic processes will also influence the assemblage present at a given location (e.g. Sousa, 1984; Reed et al., 2000). A large number of factors and interactions among them will create complex patterns in the distribution of organisms as well as variation of these patterns in time and space (e.g. Martin et al., 1993; Åberg \& Pavia 1997; Airoldi, 2000). A basic knowledge of how natural processes and interactions generate variability of species in space and time is essential to predict how the deployment of defence structures will influence coastal assemblages and to identify sustainable design options. Broad qualitative forecasts of the kinds of species and the sequences of change on or around a defence structure can be made with some confidence. Quantitative predictions of the effects on individual species and assemblages at any particular location are more difficult. Furthermore, systems change over time naturally and in response to human interventions. A sustainable design of defence structures needs to consider the local environmental characteristics and potential temporal changes.

\section{The importance of scale: interactions between local- and broad-scale processes}

Environmental factors affecting the distribution and abundance of species and maintaining biodiversity operate on different spatial and temporal scales (Fig. 1). On a broad geographic scale $(100 \mathrm{~s} \mathrm{~km})$ the species pool in a particular region is determined by past geological and evolutionary processes coupled with the influence of major physical factors such as climate, major currents, upwelling, tidal excursion and salinity (UNEP, 1995). Examples of factors operating on a mesoscale (within coastline, 1-100 
$\mathrm{km}$ ) are coastal geology and geomorphology, residual currents, wave regime, nutrient supply due to small scale upwelling and riverine run off. These factors will on this scale mainly affect the connectivity of habitats through variation in dispersal, larval supply and recruitment (Gaylord et al., 2002). On a local scale (1m - $1 \mathrm{~km})$, interactions between species and interactions between species and their physical environment become extremely important. For shallow water organisms, important physical factors include exposure to wave action, desiccation stress, and scour from sediment and other debris (Dayton, 1971; Sousa, 1984; Airoldi, 2003). Important biological interactions include competition for resources such as food, nutrients, light and space, grazing and predation (Southward, 1964, Hawkins and Hartnoll, 1983). Other examples of interactions on this scale are biologically mediated disturbance such as algae sweeping surrounding rock surface which may reduce recruitment and survival of other organism (Kennelly, 1989). Finally, on a smaller scale $(<1 \mathrm{~m})$, the abundance of some species may be determined by the availability of physically and biologically provided microhabitats. For example on hard substrata microhabitats vary due to drainage, aspect, slope, roughness, complexity, presence of organisms acting as ecosystem engineers and micro-scale water movements (e.g. Beck 1998). On soft bottoms, microhabitats are generated by changes in grain size and texture. The attributes of coastal habitats and assemblages also vary over a range of temporal scales, with complex interactions between spatial and temporal scales (Fig. 1). Thus, the abundance of a species may fluctuate considerably when looking at a small spatial scale but be stable when comparing the average abundance on a larger scale.

To understand and predict the effects of management interventions (e.g., coastal defences) on biodiversity, we must consider how ecological processes might be impacted not just locally $(1-10 \mathrm{~km})$ but also regionally (10's-100's of kms). For examples specific local effects of coastal defence structures on recruitment of organisms may lead to changes in regional distribution patterns if native and non-native species can use multiple structures as stepping stones for dispersal across coastlines (see below paragraph 5.2. "Impacts at regional scales"). Similar mechanisms operate when managing desired natural resources on coastal defence structures which may require actions at a regional scale to prevent local extinction due to habitat fragmentation. 


\section{What is an environmental impact?}

Humans depend on coastal environments for food, energy, construction, recreation and many other resources and services. The use of these resources inevitably has an influence on the coastal environment and associated marine life. Most frequently changes arise as a result of the many activities that occur within the coastal zone (French, 1997). Some of these changes, however, are intentionally caused by engineers or coastal managers. Any changes to the environment and/or associated biological resources as a consequence of human activities (no matter whether deliberate or accidental) are generally referred to as environmental impacts. Human activities are not necessarily incompatible with the maintenance of the coastal environment and of the goods and services it can provide. Sustainability should be regarded as a guiding principle for development, where sustainability may be defined as the use of components of the environment in a way and at a rate that do not irreversibly harm natural biodiversity, ecosystem functioning or the ability to provide ecosystem services (UNEP, 1995).

A useful perspective for approaching and managing impacts is to identify changes in the environment from one state to another (e.g. Knowlton, 1992). Often environmental change is compared to a "natural", "undisturbed" or "pristine" or reference state. However, this is often difficult from a management perspective when "natural" is defined as an environment that is not being affected by anthropogenic activities (Angermeier, 1994). Few coastal environments (if any) can today be regarded as "natural" in the sense that the non-human components are independent from anthropogenic effects (Jackson and Sala, 2001). Even a coast without human development is affected by regional processes on the land or at sea such as freshwater inflow, sedimentation, excess input of upstream nutrients and threats such as oil spills and pollutants. It is thus not possible to identify any single fundamental "baseline" environmental state that can be referred to in an objective way.

Indeed, the pertinent question from a management perspective is what environmental state is desired. This question is fundamental as each environmental state may differ with respect to landscape features, habitat and species composition, ecosystem 
functioning and hence ability to provide goods and services (Costanza et al., 1997). When a desired environmental state can be defined, it is essential that the natural processes responsible for maintaining that state are known or identified. Impacts may change the ecosystems from desirable to undesirable states, at worst affecting sustainability of the system. When ecosystems are driven through thresholds of undesirable states, losses can be long-lasting or even permanent (Scheffer, 2001; Hawkins et al., 2002). Our present ability to restore habitats is very much in question (Minello and Webb, 1997; Zedler, 2000), and opportunities for restoration can be extremely expensive or even impossible (Costanza et al., 1997). For example, many of the problems of erosion and flooding along European coastlines arise from the destruction of the natural features of the coast that act as sediment stores (e.g. beaches, dunes, marshes, and seagrass meadows), which has irretrievably compromised natural coastal defences leading to the necessity of expensive engineering interventions (French, 1997).

Many environments that today are perceived as "natural" are shaped and dependent on human intervention (e.g. fire-protected forests, alpine meadows, sand beaches). Sometimes the management policy is to minimize anthropogenic effects (e.g. when setting aside areas as nature reserves), and achieve areas where the non-human components of the environment develop with a minimum of human intervention (e.g. Habitats Directive, EEC, 1992). The rationale may be for ecosystem or wild-life conservation, recreational use, or research. The nature reserve may still rely on a management strategy to maintain the environment at a particular state. We here argue that referring to a "natural" environmental state or to "positive" and "negative" impacts detracts from identifying efficient management strategies. Different options in coastal management, such as deployment of LCS or other defence structures, beach nourishment or to leave the coast unprotected are best evaluated in terms of the desired environment state and what management strategy is required by various stakeholders. Ideally this should be decided in a political process that incorporates the views of many stakeholders and attempts to resolve conflicts amongst them.

\section{Impacts of hard structures for coastal defence}


LCSs as any other hard defence structures will have consequences for the coastal landscape and for the structure and functioning of coastal ecosystems. These consequences can occur locally $(10-1000 \mathrm{~m})$, but also scale up to surrounding areas and ultimately affect coastal ecosystems on a regional (coastal cell) scale $(100-1000 \mathrm{~km})$. The variability of ecological systems makes it difficult to predict quantitatively the impacts of an LCS in a specific area. Nevertheless, results of the DELOS project suggest some qualitative general impacts and identify areas for concern (Table 1).

\subsection{Impacts at local scales}

The type and magnitude of the changes induced by the LCS can vary considerably depending on the environmental setting where the breakwaters are built. However, the construction of LCS and other types of hard defence structures always results in a local loss of natural soft bottom habitats and associated assemblages of animals and plants. Although the surface covered by any individual structure or schemes of structures is limited, the large number of structures in some areas may sum up to significant losses. For example, construction of LCSs has affected over $60 \%$ of the natural landscape in the intertidal and shallow subtidal habitats over about $130 \mathrm{~km}$ of coast in Emilia Romagna in the north Adriatic sea (Cencini, 1998; data from the DELOS project).

There are also direct effects on surrounding soft bottom habitats as a consequence of the primary objective of the structure itself, which is to reduce wave energy and alter depositional processes. Such alterations induce a disruption in the normal succession of assemblages from deep waters to the shoreline and directly influence the characteristics of soft bottom sediments (i.e. grain size, content of organic matter, Redox conditions), leading to changes in the composition and/or abundance of animals and plants living in and on the soft bottoms (Davis et al., 1982; Barros et al., 2001; Martin et al., this issue). Changes are most evident just around the structure, on the seaward side due to the increased wave energy and on the landward side due to decreased wave energy. Periods with calm weather conditions may also lead to stagnant water and a degradation of water quality. For example, the defence scheme at Lido di Dante (a DELOS case study), which includes two LCSs and lateral groynes, has created a water enclosure that 
approximates a lagoon system with significant water quality problems because of low flow. Changes in sedimentation patterns of the coastal cell may impact not only the immediate sea bottoms but also nearby upstream/downstream areas affected by newly erosion/sedimentation processes, with possible negative consequences for adjacent habitats, including underwater vegetation.

The addition of artificial hard substrates fragments coastal sandy habitats and can lead to uncharacteristic changes, often increases, in local biodiversity. In control areas without LCS, sediments are dominated by just a few species, a common characteristic of this dynamic environment (Rosenberg, 1995). The addition of LCS brings species in to new co-occurrences within an area. This change in species richness represents a substantial modification of the natural characteristics of the biotope (Angermeier, 1994). The presence of high densities of opportunistic species (generally on the landward side), as well as the accidental presence of hard bottom species in the soft bottoms (e.g. mussels and crabs) is a general trend that has been observed in all DELOS case study sites. The ecological implication of these kinds of changes are not fully appreciated (Sax and Gaines, 2003) and must be factored in to management decisions.

The most obvious impact from an LCS is the introduction of artificial hard bottom habitats into areas that are often characterised by a scarce occurrence of natural rocky reefs. These new hard substrata do not function as complete analogues of natural rocky reefs (see Glasby and Connell, 1999 for a review), but in all DELOS study sites in Italy, Spain, UK and Denmark the LCSs were generally colonised by animals and plants that were found in nearby rocky shores, coastal lagoons or on other artificial structures (Moschella et al., this issue). In areas dominated by sandy shores, this has resulted in the introduction of species new to these areas or in an increased abundance in species present in small numbers on other artificial substrates (e.g. Bacchiocchi and Airoldi, 2003). The resulting changes in species composition, abundance and diversity can have important consequences for the functioning of coastal ecosystems, modifying productivity and nutrient cycling (Loreau et al., 2002), ultimately affecting resources and services to humans. For example, along the coasts of Emilia Romagna, most LCSs were colonised by extensive beds of mussels and green ephemeral algae, interspersed through large patches of unoccupied space (Bacchiocchi and Airoldi, 2003). Whilst mussels were strongly targeted for recreational harvesting (Airoldi et al. 2005), growth 
of green ephemeral algae was a major problem for local beach tourism; these algae were torn off the structures and washed up the shore, affecting negatively the amenity value of the beach from where they needed to be periodically removed.

Overall, the types of assemblages that grow on these new substrata depend on many physical and biological factors acting at different spatial scales (Moschella et al., this issue). In the north Adriatic sea, for example, the composition and distribution of assemblages colonising LCSs at a regional scale was largely influenced by the location and relative proximity to natural reefs and other nearby artificial structures (Airoldi et al., unpublished data). At a local scale, in all DELOS study areas, species abundance was mostly controlled by the regime of disturbance from wave action. In particular, there was a clear difference in species composition between the wave exposed seaward side and the more sheltered landward sides of the structures (Moschella et al., this issue). Along the coasts of Emila Romagna another important factor was represented by the frequent disturbance from maintenance works that are a major source of spatial and temporal variation in species composition and abundance among nearby LCSs (Bacchiocchi, 2004). At a microscale, patchiness in species distribution was influenced by complex interactions between physical factors (e.g. micro-scale water movements), biological factors (e.g. grazing by limpets) and human disturbance (e.g. from recreational harvesting of mussels). This can be exemplified with some results of experimental work done in the UK study site where the removal of the limpet Patella vulgata on the seaward side resulted in growth of the seaweed Fucus vesiculosus, that before the removal was not present (Moschella et al., unpublished data). However, the seaweed did not grow in the whole area where limpets where removed, but in microrefuges giving some shelter from hydrodynamic forces.

\subsection{Impacts at regional scales}

Deploying a number of LCS or other hard defence structures in a region has an impact on the abundance and distribution of species on a regional scale. Such impacts are not simply the cumulative result of a number of small scale impacts; there can be emergent effects. A high number of nearby artificial structures can act as stepping stones (Fig 2), disrupting natural barriers and facilitating the dispersal of rocky coast species across habitats and regions that naturally would be poorly connected. An 
increased connectivity between natural rocky reefs can increase the gene flow within a species (Palumbi, 2003). This increased gene flow can be negative since it can reduce local adaptation within a species and thus on a larger time scale decrease the evolution of new species. The system of artificial structures can also provide new dispersal routes that permit the invasion of non-indigenous species, including pests (Lambert and Lambert, 2003; Bulleri et al., 2005; Frost and Moschella, unpublished). For example, along the north-east coast of Italy, coastal-defence structures, which run almost uninterrupted for about $300 \mathrm{~km}$, have promoted the expansion of numerous introduced species, including Codium fragile ssp. tomentosoides. Experiments done during DELOS indicate that the sheltered habitat on the landward sides of breakwaters offers particularly favourable conditions for the growth of this macroalga, thus promoting its spread along a formerly exposed sandy coast (Bulleri and Airoldi, submitted).

In the DELOS project, we studied the large-scale effects of hard defence structures using a combination of field investigations and spatial population models with the limpet Patella caerulea. Model simulations of the dispersal and survival of $P$. caerulea in the north Adriatic Sea showed that the maximum dispersal distance of this species is far less than the distance between natural rocky reefs in the area. Thus, before the deployment of LCS and other artificial structures the gene flow between natural populations in Trieste and Ancona was probably limited. Model simulation further showed that if just a few more structures were built in the area it would be equivalent to a continuous rocky coast for this species. If structures were removed from the system the model simulation showed that the proportion of occupied structures decreased. However, it also showed that some structures were more important for the dispersal than others, depending on their locations.

Overall, the results show that proliferation of coastal-defence and other types of human made structures can have critical impacts on regional species diversity. This is consistent with predictions from theoretical work and empirical evidence that indicate that species diversity changes in human-perturbed environments as a net effect of removing isolating barriers, favouring the spread of non-native species and increasing habitat heterogeneity (see Angermeier, 1994; Rebele, 1994; Glasby and Connell, 1999).

\subsection{The importance of site-specific context}


Whilst there are some general consequences of the construction of coastal defence structures, results of the DELOS project have shown that many effects are site specific, reflecting the complexity and variability of natural systems. The impacts of LCSs on both sediment fauna and hard-bottom epibiota differed quantitatively across the case study sites covered by the project (Martin et al. and Moschella et al., this issue), likely as a consequence of differences in oceanographic conditions, tidal regime, prevailing habitat type, native species pools and anthropogenic pressure on the coast. The environmental effects of coastal defences were greatest along the coasts of the North Adriatic sea as compared to the other case studies in the UK, Spain and Denmark. The high concentration of human activities and proliferation of hard-defence and other artificial structures in the sensitive region of the North Adriatic have lead to interactive effects of coastal defence structures with other local impacts, such as regional eutrophication, recreational harvesting, local depletion of living resources, high rates of introduction of exotic species (Cencini, 1998; Correggiari et al., 1992; Airoldi et al., 2005; Bulleri et al., 2005). Further, even within this region, structures were colonised by different assemblages, depending on their location and on the relative distances from natural rocky shores or other artificial structures (Airoldi et al. unpublished data).

The site-specific differences in the type and amount of species that grow on the structures can be relevant also to the design of the structures themselves. For example, some species (such as mussels or tube-building polychaetes) which characteristically colonize structures in some places in high abundances can significantly reduce the original porosity of the structures, with consequences for its functioning (e.g.Wilkinson et al., 1996). Knowledge of the environmental and social context in which LCSs are placed is fundamental to an effective design and management of coastal defence structures. Whilst this is a well known principle (Bergen et al., 2001), carefully designed research efforts are needed at a pre-design stage to identify and quantify the site-specific impacts of coastal defence structures and to establish the efficacy of design options to mitigate such impacts.

\section{Advice for a sustainable long-term management of LCSs}


Once it has been decided to build a structure on rational grounds to protect an area of coastline there will inevitably be consequences for the environment. The ecological conditions of the site will be changed from its previous natural or semi-natural state in most cases, although on some heavily modified coastlines the change will be from one set of artificial conditions to another. In most countries it is a requirement that design options are considered that minimise impacts of human actions on existing environmental conditions. While it may be possible to minimize some of the effects of LCS on soft-bottom biota, some impacts are unavoidable and must be factored in to the decision of whether or not to use this management approach. Further, whilst minimization of impacts is generally a priority in sensitive or ecologically valuable coastal landscapes (for example seagrass meadows that are important engineering species in the coastal zone providing sediment stability and a refuge for highly diverse assemblages), in severely degraded or heavily managed environments minimization of changes may not be the "desired" (sensu paragraph 4) management end-point. It may also be possible to identify design options that maximise some of the byproducts of the structures to meet specific secondary management end points. For examples, it may be possible and desirable to maximize areas that provide nursery habitat for key fished species (see Martin et al., this issue), maximize the growth of filter feeders to improve water quality and transparency (Wilkinson et al., 1996), or maximize habitat for marine wildlife that are the focus of conservation, recreation or education (see Moschella et al., this issue). The use and design of LCS will vary based on these different objectives. The effective design and use of coastal defence structures requires (i) the clear identification of expected outcomes, (ii) evaluation of the ecological and economical consequences in the light of the regional environmental and social context and (iii) sound monitoring to assess their effectiveness at meeting management objectives (Table 3). Sound monitoring requires forethought. The best monitoring designs sample areas at multiple times and places before and after a putative impact, such as the placement of a hard defence structure. These are known as "BACI" designs and further improvements (Green, 1979; Underwood, 1994; Benedetti-Cecchi, 2001; Hewitt et al., 2001), and are well established globally. These designs not only provide information about current projects, but also provide useful predictive value for proposed projects elsewhere. 
Based on results of the DELOS project, past experience and general ecological knowledge, Martin et al. (this issue) and Moschella et al. (this issue) have identified some key factors that affect the type and magnitude of impacts of coastal defence structures on soft-bottom and hard-bottom assemblages and on mobile fauna (Table 2). Whilst referring to those two papers for a discussion of the ecological impacts expected as a consequence of different design alternatives of LCSs, here we offer some general advice about options to mitigate impacts of LCSs on existing soft-bottom depositional ecosystems and to manage the growth of epibiota (Table 3). We further incorporate recent theoretical and empirical knowledge in population and landscape ecology as a framework to guide the design of coastal defence efforts over large spatial scales.

\subsection{Advice for mitigating impacts of LCSs on existing depositional ecosystems}

As discussed by Martin et al. (this issue) and summarized in paragraph 5.1., coastal defence structures can affect surrounding soft-bottom environments and associated biota in several ways; for example by habitat disruption, modification of water flow, sediment characteristics and detritus pathways, and predation by fish or other mobile predators. Although it is impossible to avoid the disruption of the sediments where LCSs are constructed, the construction impact could be significantly mitigated if the works are carried out from the sea instead of land-based construction. Land based construction can damage fringing maritime communities such as dunes and vegetated shingle beaches. Once constructed, mitigation of impacts can be ensured by avoiding reworking on the structure, which would delay recovery (see also the following paragraph 6.2).

The extent of the modifications to surrounding sediments is greatly influenced by the design of the structure. Results of the DELOS project suggest that if water flow through the structure is much reduced, the habitat on the landward side may suffer severe modifications (Martin et al, this issue) because of the local sheltered conditions that favour deposition of finer and organically enriched sediments. This will lead to reduction or disappearance of native species and, at the same time, will create new conditions for species more adapted to the new type of habitat, including invasive species. Structures allowing greater water flow from the seaward to the landward side can mitigate such changes, and help maintain similar habitat conditions and sediment characteristics at both sides of the structure. Severe confinement (as 
produced by the use of lateral groynes to enclose the landward area of LCSs) should be avoided to mitigate persistent accumulations of organic materials such as algal or seagrass debris in the sheltered side of the structure, which could lead to stagnant poor water quality and greater biological oxygen demand.

\subsection{Advice to manage growth of epibiota}

The epibiota on LCSs are the most visible of all the species and there are often substantial socio-economic considerations that will influence the design of structures, which depends on whether or not these species are perceived as desirable or undesirable (see Moschella et al., this issue, for a discussion about the effects of the characteristics of the artificial substrata and the design of the structures on the abundance and diversity of epibiota). As noted above some of these species may be desirable because they are harvestable (e.g. mussels, crabs, oysters, limpets) or are enjoyable when bird watching or snorkeling. However, these artificial habitats also change the native characteristics of the areas, and can cause increases in non-native, nuisance or other undesirable species.

A major challenge when considering sustainable management of epibiota is that in the regions lacking nearby comparable natural rocky shores (such as the DELOS case study of the Emilia Romagna coast, but similar case studies occur both within Europe and other non-European countries) it is difficult to assess whether assemblages occurring on coastal defence structures are representative of those that would have naturally occurred on rocky shores if present. Therefore, in these regions there is not one easily identifiable management goal (e.g. promoting the development of assemblages as close as possible to those occurring on nearby natural shores), and it is difficult to give advice about which type of assemblages should be promoted or prevented to mitigate impacts. Preventing growth of fouling is in general very difficult (Wahl, 1989) and attempts in this direction would probably be very expensive if even feasible. Certainly, the most recommended advise to mitigate the impacts due to the introduction of hard-bottom species is to prevent proliferation of structures by minimizing downstream effects and implementing sound eco-regional strategic planning for coastal cells (see Table 3, see also paragraph 6.3). Proliferation of structures can lead, in fact, to broad-scale alteration of the whole coastline, which cannot be predicted by scaling up local impacts. 
Results of the DELOS project have also shown that from an environmental point of view the project lifetime and required maintenance is one of the most crucial factors affecting the composition, abundance and distribution of species that colonise the structures themselves. For instance, along the Italian coasts of the North Adriatic Sea, frequent maintenance of structures by adding new blocks to the crest has dramatic effects on epibiota (Bacchiocchi, 2004). Such frequent and severe disturbance effectively maintains assemblages at an early stage of succession, with few species compared to those on structures which have not been maintained, and favors the development of green ephemeral algae, with consequent negative effects on the quality of the beach. For any new structure introduced into the marine environment it will take time for mature biological communities to develop. Thus, to promote mature assemblages, coastal defence structures need to be stable and built in such a way that maintenance will be minimal. Unless defence structures meet these criteria, there is little point in introducing additional features to meet specific secondary end-points (for example enhancing habitat complexity to promote diverse assemblages for ecotourism), as attempts to repair the structure will result in considerable degradation of developing assemblages.

\subsection{Population and landscape ecological principles and their relation to LCSS}

Some of the best information on the regional design of LCS comes from recent work on the design of marine protected area networks. The most efficient marine reserves, to protect biodiversity, genetic diversity and ecosystem functioning, are those that are made in networks where the connectivity is evaluated such that the local processes are enhanced to a regional level (e.g., Lubchenco et al., 2003). Such marine networks have made conservation efforts more successful and goods and services are optimised. While the goal of marine reserves is conservation and enhancement of native diversity, in the case of LCS the goals may be to reduce these impacts in a regional context. The regional effects of LCS include: increased abundance and incidence of rocky shore species, decreased abundance and incidence of soft sediment species, changed composition/structure, increased gene flow, and increased non-native species.

From marine reserve theory, we know that connectivity depends on the spacing of reserves and recent papers have given advice for example on appropriate spacing to aid 
gene flow. For example, Kinlan and Gaines (2003) suggest that in California reserves would have to be placed no farther than $20 \mathrm{~km}$ apart to ensure maximum dispersal of native species. A similar approach could be taken for LCSs, where consideration could be given to how close defence schemes should be placed. If there are species (e.g., nonindigenous pests) for which spread is undesirable, then LCSs schemes could be placed farther apart than typical dispersal distances for these species. It is, however, important to note that, as also stated above, simulations have shown a strong dependency on the specific locations. Thus the absolute amount of artificial habitat may not be as important as the explicit placement of LCS.

\section{Main lessons from DELOS}

Erosion is a natural process in naturally dynamic areas. Many problems of coastal erosion are, however, made worse by the impact of humans on the coast, and there is growing concern about the predicted future trends of increased storminess and rising sea level due to climate change (EUCC, 2004). The dilemma facing coastal managers is whether to defend an eroding coast, how to defend the coast, and at what socioeconomic cost (French, 1997). There is an increasing concern about the ecological implications of coastal hardening and the long-term sustainability of sea defence. The DELOS project clearly points out that coastal erosion varies among the different regions, which require different solutions with different environmental consequences. For example, whilst the construction of a localised defence scheme at Elmer (UK) did not seem to pose particularly serious threats to coastal habitat or assemblages in that region (Hawkins et al, unpublished data), the proliferation of hard defence structures along the Italian coast of the North Adriatic sea has substantially changed the identity and nature of the coastal landscape of this region (Airoldi et al., unpublished data). The ecological effects of these alterations can now be seen not only on a local scale (Bacchiocchi \& Airoldi, 2003), but have propagated upward affecting the composition and distribution of biota at a regional scale (e.g. Bulleri et al., 2005). Successful management can only be achieved by treating the whole coast as an integrated unit, 
where the ecological consequences are evaluated in the light of a regional environmental and societal framework.

The results of the DELOS project also point out that to inform sustainable defence measures ecological knowledge is necessary about both local scale and large-scale effects of coastal defence structures. In most developed countries, it is now common that some form of environmental impact assessment (i.e. a study that documents the project, reasonable alternatives to the proposed project, an overview of the natural environment that will be affected, and the environmental consequences) be required before urban developments can proceed. Most of these studies, however, cover very limited spatial scales, focussing on local environmental conditions at the site where the construction is planned. Further, post-impact studies after the development has been completed are rarely done, limiting greatly the knowledge of the full impact of the resulting changes to coastal habitats and assemblages (as well as the capacity of prediction in case of new deployments). Predicting the effects of anthropogenic activities on organisms and environments is fundamentally important to ensure adequate management and conservation of natural environments. Thus resources need to be devoted to monitor the coastal environment and changes that occur from the placement of coastal defence structures and any other hard artificial structure. Future work should attempt to characterize more deeply how the type, quality and spatial arrangement (e.g. location relative to natural habitats and other artificial habitats) of fragmented artificial habitat patches affect the dispersal and distribution of species at a regional landscape scale, and the implications of these changes on the functioning of ecological systems at all spatial scales.

It is not possible to build LCSs without their being some impacts on natural habitats, and mitigating the impacts of hard-defences can be difficult. It is possible to optimise some of the unavoidable consequences of hard-defence structures to meet specific secondary management goals (e.g. optimise habitat for wildlife that is the focus of recreational use). The social and economical benefits of such outcomes should, however, be carefully evaluated in the light of environmental costs. Current evidence both from DELOS and other research (Glasby and Connell, 1999, Davis et al., 2002, Lambert and Lambert, 2003) clearly shows that some of the ecological impacts occurring as a consequence of the hardening of whole coastal areas can be more serious 
than have been generally appreciated, and could lead to substantial modifications of coastal habitats. Appropriate consideration of whether or not coastal defence structures should be built requires a clear statement of goals and a consideration of the environmental consequences at local and regional scales. If structures are deemed necessary and appropriate, then sound monitoring before and after construction is required to assess their effectiveness at meeting management goals.

\section{Acknowledgments}

We wish to thank all DELOS participants for stimulating discussions during the project, that lead us to view under different perspectives the problem of coastal defence. We also thank Antonio Terlizzi and another anonymous reviewer for useful comments on the manuscript. L.A. is grateful to Fabio Bulleri and Francesca Bacchiocchi for stimulating discussion and inputs of ideas while writing. Work was supported by funds from the EU project DELOS (EVK3-CT-2000-00041). Further funding from the project COFIN (ex 40\%) to M. A. During the work, L.A. was supported by an "Assegno di Ricerca" of the University of Bologna.

\section{References}

Åberg, P., \& Pavia, H. 1997 Temporal and multiple scale spatial variation in juvenile and adult abundance of the brown alga Ascophyllum nodosum. Mar. Ecol. Prog. Ser., 158, 111-119.

Airoldi, L., 2000. Responses of algae with different life histories to temporal and spatial variability of disturbance in subtidal reefs. Mar. Ecol. Prog. Ser., 195: 81-92.

Airoldi, L., 2003. The effects of sedimentation on rocky coast assemblages. Oceanogr. Mar. Biol. Annu. Rev., 41: 161-263.

Airoldi, L., Bacchiocchi, F., Cagliola, C., Bulleri F., and Abbiati M., 2005. Impact of recreational harvesting on assemblages in artificial rocky habitats. Mar. Ecol. Prog. Ser., in press.

Angermeier, P.L., 1994. Does biodiversity include artificial diversity? Cons. Biol., 8: 600-602.

Bacchiocchi, F., 2004. Distribution, structure and variability of intertidal assemblages on human-made structures in the North Adriatic Sea. Phd Thesis, University of Parma, Italy.

Bacchiocchi, F. and Airoldi, L., 2003. Distribution and dynamics of epibiota on hard structures for coastal protection. Est. Coast. Shelf. Sci., 56: 1157-1166.

Barros, F., Underwood, A.J., and Lindegarth, M., 2001. The influence of rocky reefs on the structure of benthic macrofauna in nearby soft-sediments. Est. Coast. Shelf. Sci., 52: 191-199. 
Beck, M. W. 1998 Comparison of the measurement and effects of habitat structure on gastropods in rocky intertidal and mangrove habitats. Mar. Ecol. Prog. Ser. 169: 165-178.

Benedetti-Cecchi, L. 2001 Beyond BACI: optimization of environmental sampling designs through monitoring and simulation. Ecol. Appl., 11, 783-799.

Bergen, S., Bolton, S.M., and Fridley, J.L., 2001. Design principles for ecological engineering. Ecol. Eng., 18: 201-210.

Bondesan, M., Castiglioni, G.B., Elmi, C., Gabbbianelli, G., Marocco, R., Pirazzoli, P.A., and Tomasin, A., 1995. Coastal areas at risk from storm surges and sea-level rise in Northeastern Italy. J. Coast. Res., 11: 1354-1379.

Bray, M.J. and Hooke, J.M., 1997. Prediction of soft-cliff retreat with accelerating sea-level rise. J. Coast. Res., 13: 453-467.

Bulleri, F., Abbiati, M., and Airoldi, L., 2005. The colonisation of artificial human-made structures by the invasive alga Codium fragile ssp. tomentosoides in the north Adriatic Sea (NE Mediterranean). Hydrobiologia, in press.

Bulleri, F. and Airoldi, L. submitted. Artificial structures as habitats for non-indigenous species: factors facilitating the proliferation of Codium fragile ssp. tomentosoides in the north Adriatic Sea. J. Applied Ecol.

Cencini, C., 1998. Physical processes and human activities in the evolution of the Po delta, Italy. J. Coast. Res., 14: 774-793 .

Chapman, M.G. and Bulleri, F., 2003. Intertidal seawalls - new feautures of landscape in intertidal environements. Landsc. Urban Planning, 62: 159-172.

Commission Européenne, 1999 Vers une stratégie européenne d'aménagement intégré des zones côtières (AIZC). Principes généraux et options politiques. Office des publications officielles des Communautés européennes. Luxembourg, Belgium.

Connell, S.D., 2001. Urban structures as marine habitats: an experimental comparison of the composition and abundance of subtidal epibiota among pilings, pontoons and rocky reefs. Mar. Environ. Res., 52: 115-125.

Connell, S.D. and Glasby, T.M., 1999. Do urban structures influence local abundance and diversity of subtidal epibiota? A case study from Sydney Harbour, Australia. Mar. Environ. Res., 47: 373-387.

Correggiari, A., Frascari, F., Miserocchi, S., and Fontana, D., 1992. Breakwaters and eutrophication along the Emila-Romagna coast. In: R.A. Vollenweider, R. Marchetti, and R. Viviani (Editors), Marine coastal eutrophication. The response of marine transitional systems to human impact: problems and perspectives for restoration. Elsevier, Amsterdam, pp. 277-290.

Costanza, R., d'Arge, R., de Groot, R., Farber, S., Grasso, M., Hannon, B., Limburg, K., Naeem, S., O'Neill, R. V., Paruelo, J., Raskin, R. G., Sutton, P., \& van den Belt, M. 1997 The value of the world's ecosystem services and natural capital. Nature, 387, 253-260.

Davis, J.L.D., Levin, L.A., and Walther, S.M., 2002. Artificial armored shorelines: sites for open-coast species in a southern California bay. Mar. Biol., 140: 1249-1262.

Davis, N., VanBlaricom, G.R., and Dayton, P.K., 1982. Man-made structures on marine sediments: 
effects on adjacent benthic communities. Mar. Biol., 70: 295-303.

Dayton, P.K., 1971. Competition, disturbance, and community organization: the provision and subsequent utilization of space in a rocky intertidal community. Ecol. Monogr., 41: 351-389.

ECUS, 2003. Guidance for coastal defence design in relation to their landscape and visual impacts. CCW Contract Science $\quad \mathrm{N}^{\circ}$ Report [Online] URL: http://www.ccw.gov.uk/Images_Client/Reports/Guidance\%20for\%20coastal\%20defence.pdf .

EEC, 1992. Directive on the conservation of natural and semi-natural habitats and of wild fauna and flora (92/43/EEC) (Habitats Directive). [online] URL: http://www.ecnc.nl/doc/europe/legislat/habidire.html.

EUCC - The Coastal Union, 2004. Trends of coastal erosion in Europe. URL: http://www.eurosion.org/reports-online/reports.html, [online].

European Environment Agency, 1995. The Dobris assessment. Chapter 35: Coastal zone threats and management. [online] URL: http://reports.eea.eu.int/92-826-5409-5/en/page035new.html

French, P.W., 1997. Coastal and estuarine management. Routledge, London.

Gaylord, B., Reed, D.C., Raimondi, P.T., Washburn, L., and McLean, S.R., 2002. A physically based model of macroalgal spore dispersal in the wave and current-dominated nearshore. Ecology, 83: 12391251.

Glasby, T.M. and Connell, S.D., 1999. Urban structures as marine habitats. Ambio, 28: 595-598.

Gray, J.S., 1997. Marine biodiversity: patterns, threats and conservation needs. Biodiversity and Conserv., 6: $153-175$.

Green, R.H., 1979. Sampling design and statistical methods for environmental biologist. John Wiley \& Sons, New York.

Hammond, A., 1992. World resources 1992-1993: towards sustainable development. Oxford University Press, Oxford.

Hanski, I. and Gilpin, M.E., 1997. Metapopulation biology, ecology, genetics and evolution. Academic Press, San Diego, California. Academic Press, San Diego, California.

Hawkins, S.J. and Hartnoll, R.G., 1983. Grazing of intertidal algae by marine invertebrates. Oceanogr. Mar. Biol. Annu. Rev., 21: 195-282.

Hawkins, S.J., Gibbs, P.E., Pope, N.D., Burt, G.R., Chesman, B.S., Bray, S., Proud, S.V., Spence, S.K., Southward, A.J., Southward, E.A. and Langston, W.J., 2002. Recovery of polluted ecosystems: the case for long-term studies. Mar. Env. Res. 54: 215-222.

Hewitt, J.E., Thrush, S.E. and Cummings, V.J., 2001. Assessing environmental impacts: effects of spatial and temporal variability at likely impact scales. Ecol. Appl. 11: 1502-1516.

Jackson, J.B.C. and Sala, E., 2001. Unnnatural oceans. Scientia Marina, 65 (Suppl. 2): 273-281.

Kennelly, S.J., 1989. Effects of kelp canopies on understorey species due to shade and scour. Mar. Ecol. Prog. Ser. 50: 215-224.

Kinlan, B. P., \& Gaines, S. D. 2003 Propagule dispersal in marine and terrestrial environments: a community perspective. Ecology, 84: 2007-2020.

Knowlton, N., 1992. Thresholds and multiple stable states in coral reef community dynamics. Am. Zool., 
32: 674-682.

Lambert, C.C. and Lambert, G., 2003. Persistence and differential distribution of nonindigenous ascidians in harbors of the Southern California Bight. Mar. Ecol. Prog. Ser. 259: 145-161.

Loreau, M., Naeem, S., Inchausti, P., 2002. Biodiversity and ecosystem functioning - synthesis and perspectives. Oxford University Press, Oxford.

Lubchenco, J., Palumbi, S.R., Gaines, S.D. and Andelman, S., 2003. Plugging a hole in the ocean: the emerging science of marine reserves. Ecol. Appl, Supplement 13: S3-S7.

Martin, D., Ballesteros, E., Gili, J.M., and Palacín, C., 1993. Small- scale structure of infaunal polychaete communities in an estuarine environment: Methodological approach. Est. Coast. Shelf. Sci., 36: 4758.

Martin, D., Bertasi, F., Colangelo, M.A., Frost, M., Hawkins, S.J., Macpherson, E., Moschella, P.S., Satta, M.P., Thompson, R.C., deVries, M., and Ceccherelli, V.U., this issue. Ecological impacts of low crested structures on soft bottoms and mobile infauna: how to evaluate and forecast the consequences of an unavoidable modification of the native habitats. Coast. Eng.

Minello, T., and Webb, J.W. Jr., 1997. Use of natural and created Spartina alterniflora salt marshes by fishery species and other aquatic fauna in Galveston Bay, Texas, USA. Mar. Ecol. Prog. Ser. 151: 165-179.

Moschella, P., Abbiati, M., Åberg, P., Airoldi, L., Anderson, J.M., Bacchiocchi, F., Dinesen, G.E., Gacia, E., Granhag, L., Jonsson, P., Satta, M.P., Sundelöf, A., Thompson, R.C., and Hawkins, S.J., this issue. Low crested structures as artificial habitats for marine life: what grows where and why? Coast. Eng.

National Institute of Coastal and Marine Management of the Netherlands, 2004. A guide to coastal erosion management practices in Europe. European Commission Contract nr. B43301/2001/329175/MAR/B3. Directorate General Environment European Commission, [online] URL: http://www .eurosion.org/reports-online/reports.html.

Palumbi, S. R. 2003. Population genetics, demographic connectivity, and the design of marine reserves. Ecol. Appl., 13 Supplement: S146-S158.

Pickett, S.T.A. and White, P.S., 1985. The ecology of natural disturbance and patch dynamics. Academic Press, Inc., London, UK.

Rebele, F., 1994. Urban ecology and special features of urban ecosystems. Global Ecol. and Biogeogr. Letters, 4: 173-187.

Reed, D.C., Raimondi, P.T., Carr, M.H., and Goldwasser, L., 2000. The role of dispersal and disturbance in determining spatial heterogeneity in sedentary organisms. Ecology, 81: 2011-2026.

Rosenberg, R. 1995. Benthic marine fauna structured by hydrodynamic processes and food availability. Neth. J. Sea Res., 34, pp. 303-317.

Sax, D.F. and Gaines, S.D., 2003. Species diversity: from global decreases to local increases. Trends Ecol. Evol., 18: 561-566.

Scheffer, M., Carpenter, S., Foley, J.A., Folke, C., and Walker, B. 2001. Catastrophic shifts in ecosystems. Nature, 413: 591-596.

Simberloff, D., 1988. The contribution of population and community biology to conservation science. 
Ann. Rev. Ecol. Syst., 19: 473-511.

Sousa, W.P., 1984. Intertidal mosaics: patch size, propagule availability, and spatially variable patterns of succession. Ecology, 65: 1918-1935.

Southward, A.J., 1964. Limpet grazing and the control of vegetation on rocky shores. In: D.J. Crisp (Editor), Grazing in terrestrial and marine environments. Blackwell, Oxford, U.K., pp. 265-273.

Underwood, A.J., 1994. On beyond BACI: sampling designs that might reliably detect environmental disturbances. Ecol. Appl. 4: 3-15.

UNEP (United Nations Environmental Programme), 1995. Global biodiversity assessment. Cambridge University Press, UNEP Nairobi.

Wahl, M., 1989. Marine epibiosis. I. Fouling and antifouling: some basic aspects. Mar. Ecol. Prog. Ser. 58: $175-189$.

Wilkinson, S.B., Zheng, W.Z., Allen, J.R., Fielding, N.J., Wanstall, V.C.R.G., and Hawkins, S.J., 1996. Water quality improvements in Liverpool docks: the role of filter feeders in algal and nutrient dynamics. P.S.Z.N.I: Mar. Ecol., 17: 197-211.

Zedler, J.B., 2000. Progress in wetland restoration ecology. Trends Ecol. Evol., 15: 402-407. 
Table 1. Summary of main impacts expected from the construction of hard-defence structures with respect to the "do nothing" alternative, and relevant scales (both spatial and temporal $)$ of each impact. Both direction of change $(=$ increase, $=$ decrease $)$ and estimates of the current ability to make predictions $(*=$ low, $* *=$ moderate, $* * *=$ good) are indicated. $\wedge$ indicates impacts expected from the proliferation of structures over whole coastlines. For detailed explanations see text

\begin{tabular}{|l|c|c|c|c|}
\hline \multicolumn{1}{|c|}{ Factor } & Spatial scale & Temporal scale & $\begin{array}{c}\text { Direction } \\
\text { of change }\end{array}$ & Predictability \\
\hline Water flow & $\begin{array}{c}\text { Local } \\
\text { Regiona }{ }^{\wedge}\end{array}$ & $\begin{array}{c}\text { Short } \\
\text { Medium }\end{array}$ & $?$ & $* * *$ \\
$*$
\end{tabular}


Table 2. Summary of critical design features affecting the type and magnitude of effects of LCSs and other hard defence structures on coastal environments and associated biota

\begin{tabular}{|l|l|}
\hline \multicolumn{1}{|c|}{ Factor } & \multicolumn{1}{|c|}{ Predicted effects } \\
\hline Amount of structures & $\begin{array}{l}\text { Proliferation of LCSs can result in broad scale alteration of } \\
\text { whole coastline and large-scale, long term effects }\end{array}$ \\
\hline Location & $\begin{array}{l}\text { Geographical context and predominant habitat characteristics } \\
\text { are major determinants of the regional species pool, thus } \\
\text { influence the responses of coastal assemblages to structure } \\
\text { addition }\end{array}$ \\
\hline Spatial arrangement & $\begin{array}{l}\text { Distance from natural reefs and other artificial structures } \\
\text { influences dispersal of species including non indigenous } \\
\text { species }\end{array}$ \\
\hline $\begin{array}{l}\text { Height/size/porosity of } \\
\text { structures }\end{array}$ & $\begin{array}{l}\text { Permeability influences hydrodynamic conditions and } \\
\text { sediment characteristics around the structures, as well as the } \\
\text { type of epibiota that grows at the landward side }\end{array}$ \\
\hline $\begin{array}{l}\text { Project lifetime and } \\
\text { structural integrity }\end{array}$ & $\begin{array}{l}\text { Frequent and severe disturbances, as those occurring from } \\
\text { block overturning and maintenance, keep assemblages to an } \\
\text { early stage of succession and favor the development } \\
\text { opportunistic species }\end{array}$ \\
\hline $\begin{array}{l}\text { Construction material/ } \\
\text { habitat complexity }\end{array}$ & $\begin{array}{l}\text { Physico-chemical attributes may affect the local and regional } \\
\text { distribution of epibiota }\end{array}$ \\
\hline
\end{tabular}


Table 3. Advice for the development of a sustainable coastal management plan with LCSs or other hard defence structures

\begin{tabular}{|c|c|}
\hline Action & Comment \\
\hline $\begin{array}{l}\text { 1. Clearly define } \\
\text { objectives }\end{array}$ & $\begin{array}{l}\text { Identifying a priori management goals allows to develop } \\
\text { scientific predictions about the expected effects of LCS } \\
\text { and to evaluate their effectiveness }\end{array}$ \\
\hline $\begin{array}{l}\text { 2. Consider regional } \\
\text { context }\end{array}$ & $\begin{array}{l}\text { Local defence interventions, planned without an overall } \\
\text { consideration of the regional environmental conditions, } \\
\text { can lead to downstream effects and proliferation of } \\
\text { structures }\end{array}$ \\
\hline $\begin{array}{l}\text { 3. Minimize downstream } \\
\text { effects }\end{array}$ & $\begin{array}{l}\text { Impacts on adjacent habitats and beaches can magnify the } \\
\text { original problem and lead to proliferation of structures }\end{array}$ \\
\hline $\begin{array}{l}\text { 4. Avoid proliferation of } \\
\text { structures }\end{array}$ & $\begin{array}{l}\text { Hardening of whole coastal cells can lead to unpredicted } \\
\text { large-scale, long-term effects }\end{array}$ \\
\hline 5. Consider alternatives & $\begin{array}{l}\text { Alternative solutions that may have less detrimental } \\
\text { effects on the environment (including the "do nothing") } \\
\text { must be considered early when planning regional coastal } \\
\text { defence }\end{array}$ \\
\hline $\begin{array}{l}\text { 6. Implement sound } \\
\text { monitoring }\end{array}$ & $\begin{array}{l}\text { Properly designed long-term monitoring delivers } \\
\text { necessary information on changes to coastal habitats and } \\
\text { assemblages, and enables present and future management } \\
\text { decisions. }\end{array}$ \\
\hline $\begin{array}{l}\text { 7. Preserve natural } \\
\text { patterns and processes }\end{array}$ & $\begin{array}{l}\text { The type, quality and spatial arrangement of fragmented } \\
\text { artificial habitat patches should be optimised to preserve } \\
\text { natural patterns and processes rather than artificially } \\
\text { increasing species diversity }\end{array}$ \\
\hline $\begin{array}{l}\text { 8. Maximize water flow } \\
\text { on the landward side }\end{array}$ & $\begin{array}{l}\text { Structures allowing greater water flow from the } \\
\text { seaward to the landward side mitigate changes to } \\
\text { existing depositional environments and associated } \\
\text { assemblages. }\end{array}$ \\
\hline $\begin{array}{l}\text { 9. Minimize periodic } \\
\text { maintenance }\end{array}$ & $\begin{array}{l}\text { Stable structures, requiring minimal maintenance } \\
\text { (including beach nourishment), allow development of } \\
\text { mature assemblages. }\end{array}$ \\
\hline $\begin{array}{l}\text { 10. Manage human access } \\
\text { and use }\end{array}$ & $\begin{array}{l}\text { Severe human disturbance (i.e. from harvesting or } \\
\text { trampling) negatively affect benthic assemblages, and } \\
\text { maintains species abundance and diversity low }\end{array}$ \\
\hline
\end{tabular}


Time

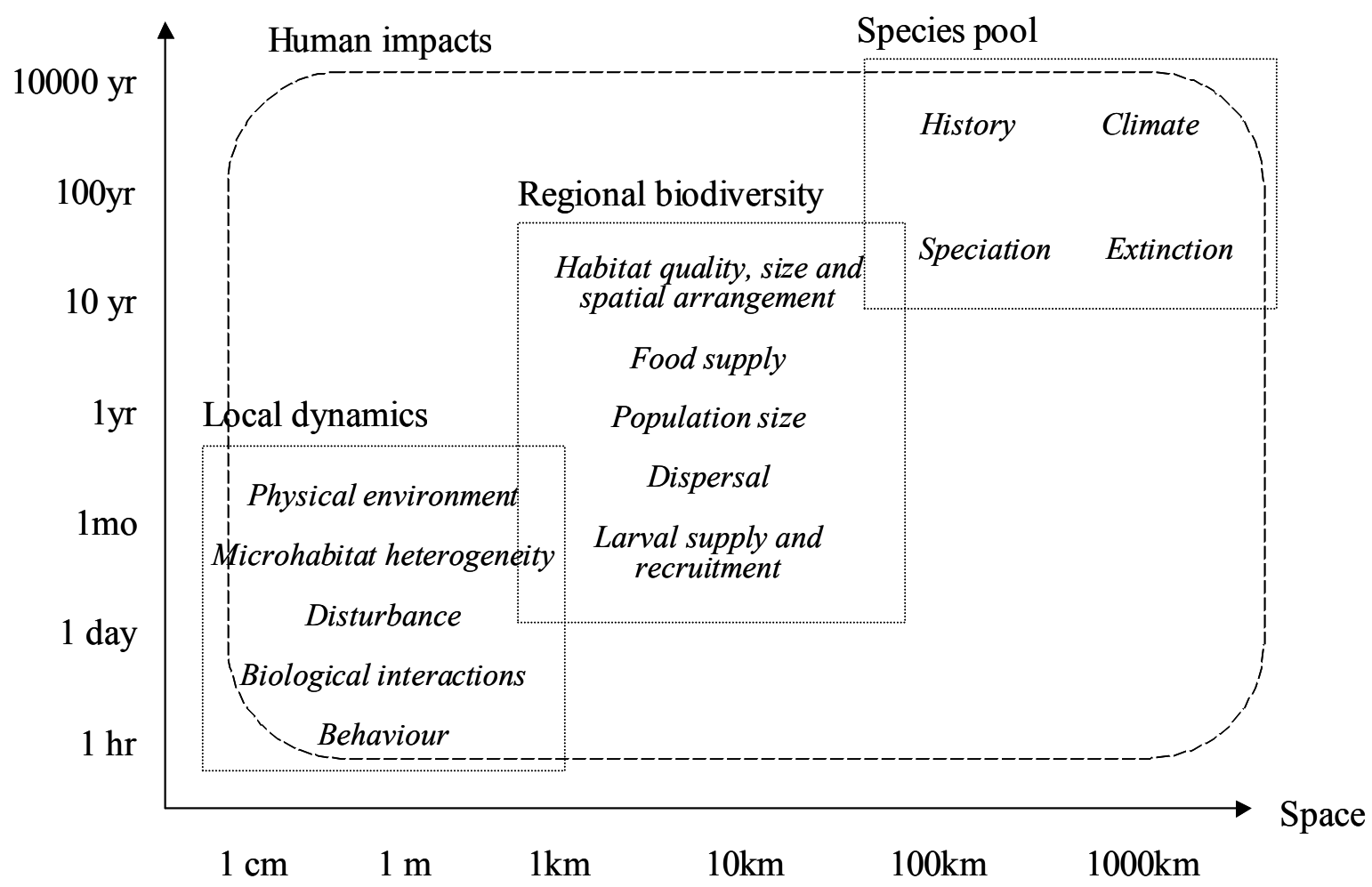

Fig 1. Schematic diagram of main processes affecting the distribution and abundance of species and maintaining biodiversity at different spatial and temporal scales. Human impacts, depicted as a dash oval, have been documented to affect biological processes at all spatial and temporal scales.

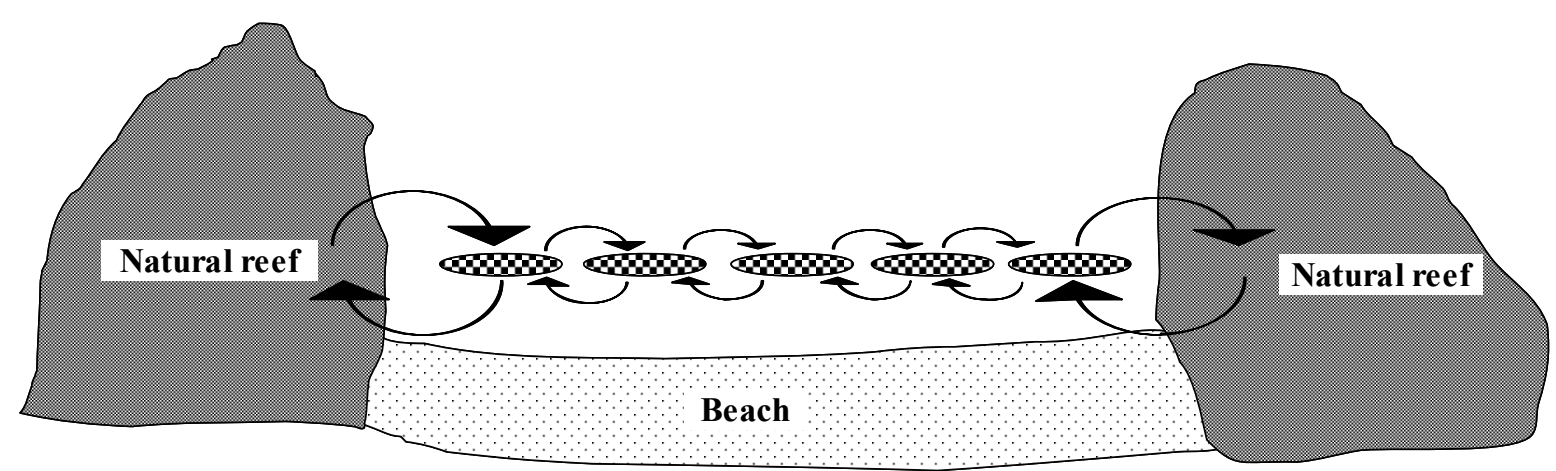

Fig 2. Schematic illustration of an hypothetical system of artificial structures acting as stepping stones. The figure, which is not to scale, is meant to depict interactions at a regional scale of 10's to 100's of kms. The proliferation of LCS, (indicated as $\infty \boldsymbol{\infty}$ ) in areas with few natural rocky substrata can favour the dispersal of species outside their natural ranges, thus increasing connectedness between naturally isolated rocky reefs. 